\title{
International trends and strategies in educational development at universities
}

\author{
James Wisdom, Visiting Professor in Educational Development, Middlesex \\ University, jameswisdom@compuserve.com.
}

\section{Reviewet artikel}

\begin{abstract}
This article considers four areas of educational development work which may become more significant in the future. The range and quality of professional development for teaching in higher education has expanded in many countries, the investment in academic frameworks of outcomes, credits and standards has yet to be exploited, the research into student learning is both productive and challenging to existing structures, and the practice of educational development is becoming more extensive - for example, practitioners are now expected to contribute to institutional strategy as much as to provide support for individual lecturers. The article notes significant changes in assumptions about the relations between students, their teachers and their courses, the need for revised approaches to assessment, and the importance of the professional development of the program leader and team to support the modernization of higher education.
\end{abstract}

\begin{abstract}
Introduction
In this paper I wish to consider four areas of educational development work which are likely to grow in their influence on the practice of higher education. These are 1) changes in the way that academics, lecturers and faculty are supported in becoming professional teachers, 2) developments in the use of learning outcomes and academic frameworks, 3) the impact of some of the work that has been done on our understanding of student learning, and finally 4) the work of educational development within universities and how it can make an impact on improving the experience of learning for students.
\end{abstract}

Developments in these four areas will be significant, not just for educational developers, but also for academics teaching their subjects, managers in departments who are shaping courses and programmes, colleagues across institutions who are supporting student learning (for example, in the library) and for university leaders who are responsible for the strategic development of their institutions. Many of the devel- 
opments are the outcomes of a growing focus on the quality and experience of the student as a learner, and have led to pressures for the re-shaping of existing practices, attitudes and relationships which up to now have served higher education well.

\section{The professional development of higher education teachers}

The International Consortium for Educational Development is made up of the national networks of educational developers from 22 countries. These networks are dealing with a number of issues concerning the professional development of higher education teachers.

The first is the question of compulsory training. Through the Consortium we have identified a few countries (Denmark, Sweden for a time) which have made it mandatory for higher education lecturers to be qualified as teachers. Some national governments have a policy of wanting their lecturers to be qualified, and support initiatives to increase the proportion. In some countries (Holland, for example), university leaders have established their own national policy. In general, individual universities adopt various positions, ranging from ensuring that taking and passing a course is an element in the decision to confirm probation, to offering opportunities and hoping lecturers use them voluntarily. In a world which values professional qualifications, it is hard to believe that the activity of teaching in higher education will remain one which requires no training or qualification other than the possession of subject knowledge.

The second is the question of standards. What does it really mean to be prepared, trained or qualified to teach in higher education? The courses can range from induction measured in days, through short courses taken in weeks, to year-long programmes leading to Postgraduate Certificates perhaps accredited by a national body. Some institutions are offering progression to Diploma or Masters Level and even PhD. In the UK we have seen the growth of the Professional Doctorate as a suitable programme for lecturers looking for the highest qualification.

The core question of standards, as well as the need for comparability and transferability between institutions and now between countries, has led in some cases to the explicit articulation of expectations. The UK has used a Professional Standards Framework since 2006 (UK PSF 2006), the Dutch Rectors have an agreement based on broad standards, and there have been European projects (e.g. Nettle - The Network of European Tertiary Level Educators (Nettle, 2005) exploring these issues. In each case, educational developers have played a significant part, and this will remain an important part of their work in forthcoming years. 
The third is the question of who might want to engage (or be encouraged to engage) with professional development. The "traditional" group has been the new full-time academic members of the university. Once this is established, attention turns to the needs of another group of staff, named in a variety of ways as postgrads, postdocs, visiting tutors, sessional staff, casual employees, adjunct faculty etc. These staff might be supervising tutorials or leading seminars, marking work under supervision, assisting on field trips, tutoring in design studios or occasionally lecturing. In some universities, students might be taught more by them than by full time academics - the professors might be in the prospectus, but the postgrads are in the classroom. Their professional development is an essential part of any university's efforts to improve the quality of the student experience and of course many are hoping to become future faculty. As institutions systematise matters such as contracts, employment status and entitlements, so the scale of activity expected from the educational development centres to support this category of staff is growing.

More attention is now focussed on new academics than on perhaps the most important group - the established lecturers who may have been teaching for many years. The growth in modern pedagogic professional development has been so extensive and so significant that there can now be very different understandings about teaching and assessing between members of even the same department. Many universities have developed progression routes for academics who want careers which move between teaching, research and administration. There are new programmes associated with reflection, portfolio, mentoring, work-based and work-related learning these are the pedagogies most appropriate for established staff who would not be able to attend traditional taught courses. The opportunities are in place for a significant expansion in this work for educational development centres.

In the UK the Staff and Educational Development Association has developed a range of 16 professional development awards which are used by institutions to design programmes for established staff, to match the different roles and responsibilities which academics take through their teaching careers - such as external examining. This same Professional Development Framework (SEDA PDF) recognises that students' learning is affected by their relationships with many more people than simply their teachers, and that a successful academic programme is delivered by a large team of people, beyond the core academic owners. So some PDF awards have been designed for the professional development of those who support learning but are not employed as departmental academics. 
In the UK, the Professional Standards Framework has been able to provide a description of the first and second level of standard (UK PSF 2006). The Framework is designed around six areas of activity, some areas of core knowledge and a set of professional values. The six areas of activity are:

1. Design and planning of learning activities and/or programmes of study

2. Teaching and/or supporting student learning

3. Assessment and giving feedback to learners

4. Developing effective environments and student support and guidance

5. Integration of scholarship, research, and professional activities with teaching and supporting learning

6. Evaluation of practice and continuing professional development.

While the areas of core knowledge and the professional values apply to both levels, those seeking recognition for the first level need only provide evidence of two of the six areas of activity. Therefore level two - which expects all six - has become the de facto standard for the mainstream, fully employed academic member of the university, who needs to understand the role of assessment in the design of modules, courses, and programmes. The "para" academic (postdoc tutor, for example) will typically concentrate on providing evidence of areas 2, 3 or 4 because they will be working within the framework designed by the module leader. SEDA now also expects that all those who are leading and managing the educational processes of institutions - deans, senior managers, even vice chancellors - should have achieved the second level of the professional standard.

However, in many universities there is still insufficient engagement with continuing professional development for teaching. The difficulties here are deep-seated and may result from unexplored assumptions about current practice. The focus on preparation for new academics, for example, has reinforced the apprenticeship induction model, with its implied message that existing practice is satisfactory and that only newcomers need to be trained. National and international reputation lists (for example, THE World University Rankings) are part of a competitive environment which in many cases takes for granted that current practice is best practice.

The educational development community has the responsibility to critique this position; for example, only 27 of the "top 200" world universities are scored for their teaching at over 70\% (THE Top 200). However successful higher education might have been in the past, the models of pedagogic practice which supported it are becoming less suitable for present conditions, and may have little place in the future. 
We must surely focus on using the research into student learning to shape pedagogic practice for the next generation of students.

\section{Developments in the use of Learning Outcomes and Frameworks}

Educational developers have been closely associated with the major initiatives to describe higher education - the use of intended learning outcomes, the construction of clear assessment criteria and the explicit statements of standards. Many universities now have modular programmes and institutional credit frameworks. Europe now has national and international academic frameworks and credit systems which enable its citizens to study beyond their national borders.

Three features of these developments may grow in significance for educational developers, especially in the way institutions learn to use these new approaches. The first feature is that institutional development is now more straightforward to manage. If a university is committed to sustainability, for example, it now has processes for reviewing explicit learning outcomes in its academic quality framework, and can ensure that all programmes have a sustainability element within them.

The second is that institutions are mistaken if they regard the exercise as complete once the framework has been constructed. The real work has only just started. At the local level, new units or modules have to be written to take advantage of the opportunities. At the institutional level, evaluation can reveal the need for significant further development. For example, unless managed very closely, modular frameworks can increase the proportion of students' summative assessment but reduce their opportunities for getting formative feedback. Reducing the number of modules per year, or offering modules across the year rather than within a semester, are two approaches which have been deployed to counteract difficulties with modularised assessment.

The third affects the position of the subject discipline within higher education. The modern graduate is someone who is often seen to be interested in interdisciplinary work and in skills development - both of these are harder to achieve when the programme learning outcomes are created by a department closely focused on its discipline. This is one of the discussions emerging from the work to implement "graduate attributes" (Barrie, 2007).

All three of these issues usually underestimate the amount of educational development work which is required to achieve change which is wholeheartedly shared by everyone involved. 


\section{The impact of research into student learning}

The third area of educational development work which is likely to grow is the impact of the research into student learning. Already this work has taught us a great deal about the relationship between teaching performance and student learning, and in significant ways has separated the two. One of the common narratives of educational development is that, while it may have had its origins in work on helping teachers improve their teaching, it has made its most significant contributions when it turned its attentions to how students learn and the impact of the whole teaching, learning, and assessment environment within which they learn (Ashwin, 2006; ETL, 2001-4)

We have four instruments which have been developed from the research and which have helped us to better understand student learning. The Course Experience Questionnaire has helped us focus on the significant elements in the student's whole experience of learning, and how they interrelate (Ramsden, 2003). The Approaches to Studying Inventory (ASI, 2000) has shown how we can design courses and assessment to increase the proportion of students intending to take a deep approach to their learning. The Approaches to Teaching Inventory (Prosser \& Trigwell, 1999) has helped us understand how teachers change their intentions and strategies for teaching according to the context in which they perceive themselves. The work around the Structure of Observed Learning Outcomes (Biggs \& Tang, 2007) has equipped us to work more effectively with learning outcomes, and has contributed to a deeper understanding of how the act of teaching may be as much about course design as about classroom performance.

One of the outcomes of this research is a renewed understanding of the significance of assessment in determining the quality of student learning (see the TESTA project). This has coincided with depressing expressions of instrumentalism from students ("if it won't be in the exam, I won't bother to learn it") which is often described as a new feature associated with the expansion of higher education - though this author can remember it as commonplace in the 1960s. It can be tracked through the "Strategic Approaches to Learning" scale of the Approaches to Study Inventory (ASI, 2000). What is more worrying, however, is the link between instrumentalism and consumerism - the notion that students are paying for their degree and are entitled to the respect due to a customer (who is, of course, always right). In the UK, this position has been caricatured by the President and Political Officer of the National Union of Students (Streeting \& Wise, 2009). 
One of the responses to the notion of "student as consumer" is the development of the concept of student engagement. In the UK this has been supported by a project conducted by the National Union of Students, with an associated web site. A model of this concept (Bols and Freeman, 2011) suggests a direction of travel from Consultation (engaging students in discussions on a deeper level than the ubiquitous end-ofmodule questionnaires), through Involvement (with students taking a more active role in shaping their learning and teaching experience), through Participation (with students making decisions about shaping the curriculum) and reaching Partnership (notions of joint ownership of the processes of learning and teaching).

At present the culture of higher education is still based on ownership of both knowledge and process solely by academics. Nevertheless, one of the outcomes of describing higher education through learning outcomes, assessment criteria, and explicit standards is that lecturers and students have a common platform for discussion about both content and process. Although it is undeniable that the language in which modern descriptions are expressed is sometime impenetrable to students and often to academic colleagues, the more students understand the processes within which they are expected to function, the better will be the quality of their learning and their overall experience.

The developments in research into learning, in understanding the role of assessment in course design, and in student engagement, are now part of the context in which the programme leader and the team is expected to operate. Higher education in the future will be designed by this group of people, especially the design of modern assessment processes which both drive learning and enable students to give good evidence of their achievement of the intended learning outcomes. The programme leader role is likely to evolve into the most important, and the most testing, position in universities. The educational developer has a major contribution to make in the development of the modern programme leader and the team.

\section{Educational development within universities}

As educational development work has developed, so the role of the educational development centre in institutions has changed as well. Educational developers have been moving from working with individual colleagues on teaching behaviour in class to working at institutional level in shaping the development of the institution.

David Gosling, in his latest survey for the UK Heads of Educational Development Group (Gosling, 2008), concludes that there are now two main areas of work: 
(1) the professional development of staff relating to learning and teaching and other academic duties (preparing for research), and

(2) a shared strategic responsibility for implementation of the learning, teaching and assessment strategy, encouragement of innovation, and enhancing teaching quality.

One of the key stages has been the focus on institutional learning and teaching strategies (Gibbs, 2000; 2001; Wisdom, 2008). Developed as a response to the apparent ineffectiveness of large national funded enhancement projects, the creation, implementation and monitoring of these strategies has deepened the relationship between heads of centres and the institution's senior management.

A survey of Australian centres (Holt et al., 2011) identified four critical factors in whether a centre was recognised and valued:

- Clarity of role and direction

- Shared understanding of purpose with the institution

- Capacity and capability to achieve purpose

- Ability to demonstrate value

The survey also identified the two areas most in need of improvement:

- Academic professional development for sessional and on-going faculty teaching staff

- Academic professional development for leaders in learning and teaching

Holt et al also identified ten leverage points in any relationship between a centre and its university. The preparation of new continuing academic staff and a compulsory casual teaching development programme are mainstream processes in many institutions (and Gosling shows them to be widespread in the UK). The notion of compulsory for "casual" but not for "new continuing" is interesting. In a survey of 85 UK institutions in 2010, Gosling (2010) found that $62 \%$ had made it mandatory for new continuing staff to complete a Postgraduate Certificate. Just-in-time professional development addresses the major issue of pedagogic support for the existing, established academics, and recognises that new forms of delivery have to be devised. Supporting teaching excellence through awards and fellowships is one of the mechanisms for raising the profile of teaching and encouraging enthusiast activity - including teaching performance in promotion criteria is often linked to this leverage point as well. However, the location of promotion prospects firmly within the research culture, and the inexperience of the awarding panels for promotion and fellowships in teaching, have made this a slow process. 
Holt et al offered three leverage points which relate to the strategic development of the institution: New visions/new plans, strategic funding for development, and renewing leadership. These map closely to the data noted in Gosling's UK study, and to the argument in this paper. Two other leverage points - disseminating exemplary practices online, and the recognition and use of education experts - have been components for some time of many educational development centres' work, and their effectiveness can be enhanced by encouraging activity around the final leverage point - forming communities of practice.

\section{Conclusion}

As the proportion of academic teachers who are engaged in their own professional teaching development grows, so will the quality and depth of the analysis and understanding of the prevailing models of higher education teaching. The focus must not be solely on classroom practice - it will need to embrace institutional frameworks and policies, because these have significant effects on the quality of student learning. Educational developers have a major role to play in shaping practice at all levels of the institution. In reforming higher education for the next generation, one of the key areas - signalled in some of the most interesting research - is the design not just of the individual modules or courses, but of the overarching programme of study. Programme leaders and the programme teams, supported in as many ways as possible by educational development, will be carrying a great responsibility for the future.

James Wisdom is a higher education consultant, specializing in educational development and evaluation. He is the President of the International Consortium for Education Development and a Visiting Professor of Educational Development at Middlesex University. He has been a Co-Chair of the Staff and Educational Development Association and is the Editor for the SEDA Series published through Routledge. He often contributes to programs for the professional development of academic staff.

\section{References}

Ashwin, P. (2006). "The development of learning and teaching in higher education: the changing context", in Ashwin, P. (ed). Changing Higher Education: The Development of Learning and Teaching. Routledge.

ASI (2000). Bibliography of Studies Using or Conceptually Related to the Approaches to Studying Inventory (ASI), Revised Approaches to Studying Inventory (RASI), Approaches and Study Skills Inventory for Students (ASSIST): http://www.ed.ac.uk/etl/questionnaires/bibliographyASI.html

(Accessed 3/6/2011).

Barrie, S. C. (2007). "A conceptual framework for the teaching and learning of generic graduate attributes", in Studies in Higher Education, 32:4, 439-458. 
Biggs, J., \& Tang, C. (2007). Teaching for Quality Learning at University. 3rd Edition. Buckingham: SRHE \& Open University Press.

Bols, A., \& Freeman, R. (2011). Engaging students in shaping their curriculum", in Educational Developments 12. 2; Staff and Educational Development Association, London.

ETL (2001-4). Enhancing Teaching-Learning Environments in Undergraduate Courses: http://www.etl.tla.ed.ac.uk/project.html (Accessed 11/7/2011).

Gosling, D. (2008). Educational Development in the UK. The Heads of Educational Development Group:

http://www.hedg.ac.uk/documents/HEDG Report final.pdf (Accessed 3/6/2011).

Gosling, D. (2010). "Professional development for new staff - how mandatory is your Post Graduate Certificate?", in Educational Developments, 11.2. SEDA, London.

Gibbs, G. (2000). "Learning and teaching strategies: the implications for educational development", in Educational Developments, 1.1. SEDA, London: http://www.seda.ac.uk/resources/files/publications 44 eddevs1 1.pdf (Accessed 3/6/2011).

Gibbs, G. (2001). "The impact of institutional learning and teaching strategies on the nature of educational development", in Educational Developments, 2.4. SEDA, London: http://www.seda.ac.uk/resources/files/publications 37 eddevs2 4.pdf (Accessed 3/6/2011).

Holt, D., Palmer, S., \& Challis, D. (2011). “Changing perspectives: teaching and learning centres' strategic contributions to academic development in Australia", in International Journal for Academic Development, Taylor and Francis.

National Union of Students project on Student Engagement: http://www.nusconnect.org.uk/campaigns/highereducation/studentengagement-hub/nus-heaproject/ (Accessed 3/6/2011).

Nettle (2005). http://www.edshare.soton.ac.uk/7337/ (Accessed 12/6/2011).

Prosser, M., \& Trigwell, K. (1999). Understanding Learning and Teaching: The Experience in Higher Education. Buckingham: SRHE \& Open University Press.

Ramsden, P. (2003). Learning to Teach in Higher Education. 2nd Edition. London: RoutledgeFalmer.

SEDA Professional Development Framework. http://www.seda.ac.uk/pdf.html (Accessed 3/6/2011).

Streeting, W., \& Wise, G. (2009). Rethinking the Values of Higher Education - Consumption, Partnership, Community?, The Quality Assurance Agency for Higher Education:

http://www.qaa.ac.uk/Publications/InformationAndGuidance/Documents/Reth inking.pdf (Accessed 11/7/2011).

TESTA (Transforming the Experience of Students through Assessment). http://www.testa.ac.uk/.

THE World University Rankings. http://www.timeshighereducation.co.uk/worlduniversity-rankings/ (Accessed 11/7/2011). 
THE Top 200. http://www.timeshighereducation.co.uk/world-universityrankings/2010-2011/top-200.html (Accessed 11/7/2011).

UK Professional Standards Framework (2006).

http://www.heacademy.ac.uk/assets/documents/rewardandrecog/ProfessionalS tandardsFramework.pdf (Accessed 3/6/2011).

Wisdom, J. (2008). "Interview with Graham Gibbs", in Educational Developments.

9.1. SEDA, London:

http://www.seda.ac.uk/resources/files/publications 12 eddev9 1.pdf (Accessed 3/6/2011). 